\title{
Jednání jako cesta k nesmrtelnosti v polis u Jana Patočky
}

\author{
Lenka Jedličková \\ Univerzity Palackého v Olomouci, CZ
}

\begin{abstract}
JEDLIČKOVÁ, L.: Interaction as a Path to Immortality in Polis by Jan Patočka

Philosophica Critica, vol. 6, 2020, no. 1, ISSN 1339-8970, pp. 52-65
\end{abstract}

\begin{abstract}
The following text attempts to map Patočka's theory of three movements of human existence from the perspective of human finality. The aim of this analysis is to prove that death not only is not an antipolitical event, but that it, on the contrary, participates fundamentally on the constitution of the human society. Not only in the form of radical sacrifices, as Patočka describes it, but also in our daily interacting with other people, in which we risk ourselves and the possibility of not being. It turns out that only because of this interaction with others and engaging in the story can we get something like immortality.
\end{abstract}

Key words: Jan Patočka - Interaction - Death - Finality Movement - Sacrifice - Polis

\section{Úvod}

Smrt je odedávna jedním z klíčových témat mnoha nejstarších mýtů, náboženství, ale i velké části metafyzického filosofického myšlení. Jen stěží pochopitelný fakt lidské konečnosti, s nímž se člověk musí během svého života vyrovnávat, je podle některých filosofů dokonce motivem pro to, že filosofujeme.

Naše vlastní konečnost je do jisté míry (a většinou ne zcela vědomě) přítomna v každém našem činu, ve všech plánech a tvoření. Přesto není tento fakt pro lidskou společnost destruktivní, jednáme a tvoříme navzdory tomu, že jsme koneční. Ba právě jen díky tomu, že jsme koneční, můžeme ve společnosti jednat a tvořit.

Jan Patočka dokonce považuje lidskou konečnost a její uvědomění za konstitutivní prvek společnosti a nezbytnou podmínku pro vstup do ní. 
Jakým způsobem se vědomí vlastní konečnosti podílí na utváření společnosti, se pokusíme ukázat v následujícím textu.

\section{Smrt jako východisko filosofie}

Ačkoli Patočka vyšel z fenomenologie, sám sebe označoval spíše za fenomenologického filosofa než za fenomenologa, přičemž zdůraznil, že se nechce zabývat jen fenomény, ale vyvozovat z nich také metafyzické důsledky (srov. Patočka 2007b, 39). To také ve své vlastní filosofické koncepci činí, ačkoli mnohdy, jak dále uvidíme, splývají tyto metafyzické závěry $s$ jeho dějinami filosofie a historickými interpretacemi.

Důležitý vliv na Patočkovu teorii lidské existence jako trojjediného životního pohybu měla kromě fenomenologie Edmunda Husserla a fundamentální ontologie Martina Heideggera také filosofie Hannah Arendtové. Právě díky ní Patočka překonal, jak se domníváme, nedostatek Heideggerovy existenciální analýzy Dasein, protože ji doplnil o intersubjektivní a politické aspekty, především pojmy plurality a jednání. Ve filosofii Jana Patočky se (bezpochyby vlivem Heideggerovy fundamentální ontologie) jakoby na pozadí, ale neustále prosakujíc na povrch, objevuje právě ona znepokojující a „temná" strana naší existence, totiž její časová omezenost, konečnost. Ta se ukazuje být klíčovou pro všechny jeho úvahy. Jak upozorňuje např́klad Cajthaml, Patočka si velmi záhy uvědomuje, že v Husserlově transcendentální fenomenologii je konečnost degradována na empirickou charakteristiku lidské bytosti, nikoli její vlastní podstatu (Cajthaml 2010,18). Právě to bylo zřejmě příčinou, že se Patočka přiklonil k Heideggerově pojetí fenomenologie (a proč tedy nechce být nazýván fenomenologem, nýbrž fenomenologickým filosofem).

O smrti hovoří Patočka ve svých dílech explicitně i nepřímo, vždy však bez veškerého patosu, což asi nejlépe vystihuje jeho vyjádření v knize Věčnost a dějinnost, kde se odvolává na Sókrata a jeho názor, že unikat pohledu na smrt je značně nefilosofický přístup. „Není to žádné zbožňování smrti, žádná mystika konce na způsob „básníků noci“ a romantických hudebníků. Je to pouze odhodlání vskutku se podívat do tváře neodvratnému, změřit je a pochopit, že v něm není před námi největší ze všech hrůz, největší zlo“(Patočka 2007c, 83-84). Tímto chce, jak se zdá, poukázat Patočka na skutečnost, že bez odhalení smyslu lidské konečnosti, kterou Heidegger provádí postupnou existenciální analýzou Dasein, se nemůžeme dobrat k vlastní filosofii. S odkazem na Sókrata se tak Patočka dostává $\mathrm{k}$ souvislosti, která hraje velkou roli v jeho koncepci lidské existence, a sice souvislosti mezi vznikem filosofie a politiky (tu reprezentuje třetí pohyb existence a není chápána $v$ úzkém smyslu, $v$ jakém ji dnes běžně 
chápeme) a uvědoměním si vlastní konečnosti. Dá se tedy říci, že v tomto bodě se spojují mezafyzické a dějinně-filosofické aspekty Patočkovy filosofie. Tímto spojníkem je právě lidská konečnost.

Patočka si je zároveň dobře vědom toho, že přes veškerou důležitost lidské konečnosti pro naše myšlení, činy i jednání ji necháváme v každodenním zaměření na věci ve světě, které nás většinou zcela pohlcují, stranou. Přiblížit se však k problému konečnosti nelze jinak než právě skrze tuto každodennost. Právě takto postupoval i Heidegger, na kterého se Patočka ve své fenomenologické filosofii odvolává. „Filosofie jakožto ontologie se opírá o konečnost jako základ: analytika lidského žití vede k fundamentální ontologii = prvním nárysem fundamentu je, že konečnost sama, třebaže umožňuje veškerý život lidský, je zapomenuta a nepochopena - jedná se o to vyrvat ji filosofickou konstrukcí tomuto zapomnění, jedná se o rozpomínku“ (Patočka 2007c, 77).

Patočku vede analýza každodennosti k formulování teorie lidské existence jako trojjediného životního pohybu, pro niž našel inspiraci nejen u Heideggera a Arendtové, ale také u Aristotela: „Co však působí, že taková bytost jako člověk je s to se nějak vyrovnat s tím světem v celku, že jej jako celek vidí, chápe a rozumí mu, rozebírá jej? Nic jiného nežli to, že jako všechny ostatní věci i člověk je bytostí pohybu, a přirozený pohyb lidské bytosti je takový pohyb, který vede nejen k tomu, že jsme tvarem pro druhé, nýbrž že sami v sobě, v tomto pohybu našeho života, odhalujeme ostatní věci a sebe samy. Náš vlastní život je pohyb“ (Patočka 2007b, 192). Patočkův výklad Aristotela nyní necháme stranou, avšak zdá se, že to byl právě Aristotelés (ke kterému se Patočka přiklání v diskusi přednášky Platón a Evropa), kdo Patočku přiměl zabývat se pojmem jednání v souvislosti s lidskou konečností.

\section{Smrt a tři pohyby existence}

Teorie tří pohybů existence má tedy, jak jsme již uvedli, více výkladů. Vedle historické interpretace a filosofie dějin ji pak ještě můžeme chápat v ontologickém či existenciálním významu. Podíváme-li se na ni s akcentem na lidskou konečnost, zdá se, že ta nejen tvoří jádro celé konstrukce, ale je právě zmíněným spojníkem obou přístupů. Domníváme se proto, že tyto dvě interpretační roviny nelze u Patočky jednoznačně oddělit. Z hlediska historického přístupu souvisí konečnost úzce s pojetím dějinnosti, kdy lidské dění Patočka člení na stupeň nedějinný, probíhající v anonymitě minulého a v ryze př́rodním rytmu, stupeň předdějinný, kde existuje kolektivní pamět' v podobě písemné tradice, a stupeň vlastních dějin (Patočka 2007a, 35). Ty mohou přijít ke slovu teprve ve chvíli, kdy člověk zpochybní dosud 
bezvýhradně přijímanou skutečnost, otřese dosavadními jistotami a začne klást otázky. Dějiny tak přicházejí ke slovu společně se vznikem filosofie, tedy teprve ve chvíli, kdy člověk zproblematizuje dosavadní smysl, a tím se vystaví nejistotě, ohrožení a riziku. Prázdnota, která se před ním objeví, jím otřese a vyžaduje nutnost postavit se jí čelem, vystát ji, a tím se stát zodpovědným a svobodným člověkem. S tímto otřesem ale neoddělitelně souvisí právě uvědomění si vlastní konečnosti.

Z hlediska lidského společenství (vrstev lidského bytí) a konečnosti pak lze tři pohyby definovat takto: První pohyb je charakterizován zakořeněním, zakotvením do věcí a mezi ně. Ochraňuje nás zde bezpečí rodiny, která je tou první, byt' jednoduchou sociální pospolitostí. Smrt je zde přítomna, avšak ještě ji nikterak neproblematizujeme, bereme ji stejně jako zvírata - jako neodvratný úděl, o němž není tř̌eba přemýšlet.

Ve druhém pohybu pak tuto elementární existenci prodlužujeme, a to prací. Sebeprodlužování a reprodukce života vytvářením věcí nás vrhá do ostrého varu reality práce a boje, ve kterém už nás nechrání společenství nejbližších lidí. Ti, kteří se kolem nás vyskytují, jsou nyní spíše spolu-pracovníky, vedle-stojícími lidmi, kteří se o nás nestarají, a my se nestaráme o ně, potřebujeme se vzájemně pouze pro výkon své práce. Jsme v tomto společenství anonymní, zastáváme společenské role a žijeme přítomností a průměrností.

Člověk zde není sebou samým, existencí v plném rozsahu, je redukován na svoji roli. Pocit bezprostřední ohroženosti našeho života je zastřen prostřednictvím cílené práce a pomocí nástrojů. „Hlavní rys je zde upoutanost života k sobě samému: 'fyzická' nutnost existovat tak, že život se věnuje na obstarávání života, na službu životu. To je ovšem jedna z podob, v nichž je stále př́tomna konečnost lidského života, jeho vychýlenost do nicoty, do smrti; je zde však ve formě neurčité, ve formě zastřenosti, kterou obstarává právě činnost, jež svou čilostí zakrývá své vlastní téma. Práce tak na rozdíl od zvírecího života - jenž svou skrovnou otevřenost stačí strávit hledáním kořisti a úživy vůbec - je v dotyku s problematičností života a zároveň zastírá výhled na ni a brání jí" (Patočka 2007a, 18).

Právě spojení práce a smrti se stalo neodvolatelným lidským údělem. A to doslova, jak zmiňuje Patočka v souvislosti s eposem o Atrachasísovi, v němž bohové, aby nemuseli pracovat, stvořili člověka z masa a krve zabitého nižšího boha - tím „vynalezli“ smrt, která se tak úzce propojila s prací. Patočka tedy konstatuje, že „lidský život je udržování se skrze práci, námahu a bolest, a pojítko mezi prací a životem je smrt" (Patočka 2007a, 20). Pohlceni prací žijeme skromně, nebouříme se proti svému osudu a jsme s ním smířeni. Nepochybujeme a neptáme se. Proto můžeme považovat svůj život za přirozeně smysluplný. 
Zde se opět, jak se zdá, vyjevuje souvislost mezi metafyzickou a historickou interpretací Patočkovy filosofie. První dva pohyby se odehrávají v jakémsi předdějinném, mytickém období, kde není nic problematického - vše je přijímáno bez pochybností, vše je zodpovězeno už dávno před naším zrozením, v minulosti. Odpovědi jsou dokonce položeny už před otázkami. Vstupem do společenství polis přecházíme do filosofie, která věci problematizuje, klade otázky, a tím nás přivádí do nejistého postavení, v němž už se nelze o nic opřít. Projevuje se to také větším akcentem na př́tomnost (na rozdíl od předchozích pohybů, kde dominuje minulost). „A s tím přirozeně přichází také to zvláštní ostřízlivění, které souvisí s tím, že pocit důvěry v jsoucno je nějakým způsobem otřesen. Proto je filosofie zvláštním způsobem nebezpečná" (Patočka 2007b, 133).

Až otřesem dosavadního akceptovaného smyslu tedy vznikají předpoklady pro ustanovení opravdového lidství. Tímto otřesem ovšem, jak Patočka zdůrazňuje, neupadáme do nesmyslnosti, ale naopak získáváme možnost objevit smysluplnost jinou, daleko významnější a hlubší. „Dějiny vznikají otřesem naivního a absolutního smyslu v téměř současném a vzájemně se podmiňujícím vzniku politiky a filosofie" (Patočka 2007a, 69). Zatímco tedy první dva pohyby jsou vnořeny do faktu své konečnosti, vyčerpávají se v pozemském přežívání a nemají sílu ani prostředky vzít si ji za svou, třetí pohyb představuje odpoutání pozornosti od jednotlivin a uvědomění si vlastní konečnosti, se kterou se musíme vyrovnat a integrovat ji do své existence. „V prvních dvou pohybech konečnost vlivem uspokojování potřeb přehlížíme („zapomněli na to jako na smrt“!)“ (Patočka 1995, 107). Právě tady Patočka zcela explicitně staví lidskou konečnost do centra dění. Teprve její plné uvědomění přivádí člověka k tomu, aby se stal dějinným a existoval „autenticky.“

Ačkoli se zdá, že význam lidské konečnosti pro Patočkovu filosofii bývá poněkud opomíjen (je to bezpochyby dáno tím, že se jí na rozdíl od Heideggera nezabýval nikterak uceleně), vychází najevo, že právě konečnost je to, co stojí v jádru jeho filosofie. Ba co víc, Patočkovým zásadním přínosem v tomto smyslu je hlavně skutečnost, že dokázal integrování vlastní konečnosti neomezit pouze na izolované Dasein, které se tím stává autentickým, ale vyvodil z tohoto uvědomění společenské důsledky. Nebot' si společně s Aristotelem plně uvědomil, že člověk je zoon politikon už ze své podstaty, nejde o náhodný atribut, který by mohl člověk nemít.

Položme si otázku: Co je ono „otřásající", co způsobuje překonání akceptovaného smyslu a opuštění dvou prvních pohybů? Zdá se, že nemusí jít o nic fatálního, na první pohled hrozivého. Ve skutečnosti je odpověd' prostší: Je to střet (jednání) s druhým člověkem a riziko s tím spojené. Riziko, protože nikdy netušíme předem, jak tento střet dopadne, a musíme 
ho tedy a priori přijmout. Tedy de facto si uvědomit, že pro nás tento střet může dopadnout špatně, uvědomit si vlastní konečnost. Třetí pohyb zde proto rozevírá novou sociální sféru, sféru spolubytí s druhým, jež pak zakládá v zásadním významu to, čemu Řekové ř́íkali polis. To, co dělá z člověka politickou bytost, je schopnost činu, jednání.

Pojem jednání je jednou z lidských činností (vedle práce a zhotovování), kterou definovala Arendtová ve Vita Activa. Podle ní se filosofie i politika zrodily ve chvíli, kdy vznikl konflikt mezi filosofem a polis, tedy v procesu se Sókratem. Sókrates je symbolem řecké polis, která v modifikované podobě přežívá dodnes, zároveň je tím, kdo jako první ukázal, že smrt se může stát účinným nástrojem v rukou člověka jakožto člena polis.

Polis je charakteristická především nejistotou, protože ve složité spleti mezilidských vztahů (přičemž už nejde o vztahy s blízkými lidmi, rodinou, ale ani o vztahy pracovní, charakteristické anonymitou a zastáváním rolí) je - jak jsme už uvedli - nemožné předem odhadnout výsledek našeho jednání s druhými. A teprve to, jak se $\mathrm{v}$ této nejisté situaci osvědčíme, určuje nakonec naši povahu, to, co jsme zač a za co nás druzí budou považovat. Přesto (nebo právě proto) do této nejistoty vstupujeme obvykle dobrovolně. A v tom, jak se snažíme tuto nejistotu vystát, přebíráme zodpovědnost a svobodu. ${ }^{1}$

Ačkoli přímá souvislost mezi konečností a politickým životem může vypadat poněkud překvapivě, zdá se, že právě toto spojení je v Patočkově filosofii skutečně klíčové. Také François Dasturová ve své knize Smrt. Esej o konečnosti při interpretaci Patočkova textu o T. G. Masarykovi zdůrazňuje, že jednání, to politické obzvlášt', je nutné chápat z perspektivy smrtelnosti. V Masarykově zakladatelském činu spatřuje Patočka naplnění heideggerovské „rozhodnosti“, která byla projevem „zodpovědného a nad biologickou úživou stojícího života“. Zodpovědný čin, má-li být skutečným počátkem, musí být spjat s pohledem na lidskou možnost smrti a schopnost tento pohled vydržet. ${ }^{2}$ Dasturová pak upozorňuje, že skutečnost inaugurovaná takovýmto činem není jen nepředvítatelná a absolutně nová, jak chce Arendtová, ale také „neodvolatelná“ a vykonaná ,jednou provždy“ což s sebou nese nezvratnost konečné časovosti“ (Dasturová 2017, 153).

Jak jsme už zmínili, tři různé základní typy vedení života a motiv nebezpečí a rizika přejímá Patočka nejspíše právě od Aristotela. Podle něj je třetí (a nejvyšší) životní formou (po životu požitkářském a životě ctižádosti ve službě obci) oddání se filosofii. Zdá se tedy, že Aristotelés oproti Patočkovi nestaví život v obci (polis) na nejvyšší úroveň - tou je až třetí

Srov. (Blecha 2018, 360-361).

Srov. (Patočka 2006, 346). 
životní stupeň, fáze filosofická. Patočka tyto dvě fáze spojuje a život v polis ztotožňuje s filosofickým kladením otázek a problematizací dosavadního smyslu a jistot (předdějinných). „Žít život strážců, žít život politických lidí, znamenalo $v$ řecké obci toto: $v$ každém okamžiku riskovat život, jak v domácích sporech, tak v konfliktech, kterým se obec nemohla vyhnout. ... A přitom život pro obec není pro Aristotela to nejvyšší. ... Také podle Aristotela je život rozumně politického, politicky žijícího člověka skoro na téže úrovni jako život filosofa" (Patočka 2007b, 205-206). Na explicitním formulování a rozvinutí aristotelské myšlenky, že konflikt, spor, polémos, je nedílnou součástí polis, má podle našeho názoru největší zásluhu právě Patočka.

\section{Polis a polémos}

V souvislosti s těmito charakteristikami pojmu jednání je pak zřejmější, proč někdy Patočka pro třetí pohyb existence používá označení „,sebezískání sebevydáním“. V tomto termínu je dle našeho názoru obsažena klíčová myšlenka celého jeho konceptu: že totiž vstupem do polis se musíme dát všanc druhému a nikdy přitom netušíme dopředu, jak tento střet s druhým dopadne. Tímto aktem se tedy přihlašujeme ke své konečnosti, integrujeme ji do své existence a přijímáme za to zodpovědnost se všemi možnými důsledky, které z toho vyplývají. V sebevydání nakonec získáváme sebe tím, že se vědomě přihlásíme ke své konečnosti a s vědomím možnosti nebýt se vystavujeme působení tohoto jednání s druhým.

$V$ tomto smyslu je však ještě třeba odlišit dvě sféry soužití s druhými - jedna z nich je sféra sociální, druhá politická. Zatímco sociální sféra se vyznačuje jistou anonymitou, v níž s druhými jednáme ve svých společenských rolích (u Patočky tak odpovídá spíše druhému pohybu existence, u Heideggera neurčitému „man“), kde sice konáme, ale nikoli jednáme, ve sféře politické jde především o to $\mathrm{z}$ těchto rolí ( $\mathrm{z}$ anonymity) vystoupit a adresně, ničím nekryt se vydat druhému všanc. Právě tím se může konstituovat lidství v jeho ryzí podobě. „POLIS je sféra adresných, cílených kontaktů, v nichž se z masy neznámých jedinců vynoří jeden či několik, s nimiž náhle mám co do činění a v nichž se soustřed'uje ona otřásající výzva k nějakému jednání" (Blecha 2018, 342).

Jak zdůrazňuje Arendtová, základní podmínkou pro jednání je fakt plurality, čili že žít znamená „prodlévat mezi lidmi“ a zemřít „přestat prodlévat mezi lidmi“. U Patočky je (na rozdíl od Heideggera, který interubjektivitu $\mathrm{v}$ tomto ohledu tak důsledně nerozvinul) druhý radikálním fenoménem, bez druhého nemůžeme jednat a být za toto jednání posuzováni, přičemž se zdá, že druhý se objevuje plně právě až tehdy, když jsme 
vyvázáni z aktivit práce. Získáváme svobodu a zodpovědnost, ale také ztrácíme pevnou základnu, protože politický život je ničím nezakotvený, je stále vystaven nejistotě a ohroženosti vlastní existence. Z otřesu dosavadních jistot a rizika, jímž se druhému dáváme všanc, odkrytosti vlastních slabých míst, nutnosti jednat, i když nechceme, z nejistoty v tom, jak druhý člověk na naše jednání zareaguje, spolu se stejnou nejistotou druhého, vytváří se nakonec pevná pospolitost vzájemně otřesených jedinců. Nejsme už chráněni svými blízkými ani společenskými rolemi, stojíme na vratké půdě. Politický život je v podstatě ničím nekrytý, vydáváme se do rizika spojeného s možností nebýt. Musíme být stále bdělí a ve střehu, svoji konečnost a pocit ohrožení máme stále před očima, plně si ji uvědomujeme.

Přesto je dle Patočky toto společenství, ač původně stojí na (alespoň zdánlivě) vratkých základech, nejpevnějším svazkem mezi lidmi. Tvrdí dokonce, že jde o jednotu ve sporu, boji, neustálém polémos. Tím ovšem dle našeho názoru nemá na mysli boj s nějakým (konkrétním či fiktivním) nepř́telem, ale pouze to, že každé jednání je svým způsobem bojem, střetem s druhým, přičemž tento střet nemusí mít negativní podtext či konotace. Boj (polémos) je zde chápán dle našeho názoru v pozitivním významu toho slova. Účastníci nebojují mezi sebou nebo proti nepříteli, ale spíše se každý sám za sebe i společně snaží překonat onen otřes dosavadního smyslu. To pak tvoří nejpevnější pouto mezi lidmi. „Jednota jím založená je hlubší než každá efemérní sympatie a zájmová koalice; v otřesenosti daného smyslu se setkávají protivníci a tvoří tím nový způsob bytí člověka - možná ten jediný, který v bouři světa poskytuje naději: jednotu otřesených, ale neohrožených... v dějinách nejde o to, co je možné vyvrátit nebo čím lze otřást, nýbrž o otevřenost pro to otřásající" (Patočka 2007a, 42). Patočka tak má skutečně na mysli jednotu, „sjednocující boj“, nikoli boj ve smyslu rozdělujícím či sjednocujícím „proti“ někomu či něčemu. Proto zdůrazňuje onu otevřenost, připravenost na otřes, který musíme vystát. Polémos je novým způsobem bytí člověka, člověka jednajícího a připraveného nést za to veškerou zodpovědnost.

Není lehké tento otřes související s uvědoměním si naší konečností vystát. Přesto se Patočka pokouší nalézt na tomto faktu pozitivní stránku. A jelikož člověka označuje v návaznosti na Heideggera jako bytost, která nejen ukazuje jsoucno, ale je také místem bytí, jež je na jsoucno neredukovatelné, je to právě ono, co nám umožňuje konečnost vnímat nejen negativně (jako něco, co jednou zmizí), ale také pozitivně. ${ }^{3}$ Pozitivní vnímání faktu konečnosti tak, zdá se, souvisí především s naší nově nabytou svobodou. Ta však s sebou nese nepř́ijemný aspekt zodpovědnosti, nutnosti

Srov. (Patočka 2007b, 135). 
se rozhodovat, a může se tak plně uskutečnit až v naší smrti. Protože náš život do té doby, dokud trvá, je ustavičně v krizi. Teprve smrt je „dokončení naší svobody, a to dokončení v tom smyslu, že ze světa věcí přecházíme k pouhému bytí“ (Patočka 2007b, 135).

\section{Obět' jako pozitivní aspekt politična}

Vstup do polis je tedy spojen s rizikem a vědomím toho, že můžeme nebýt. Nedomníváme se, že by tím měl Patočka na mysli neustálý strach z blížící se smrti, ale spíše to, že ve chvíli, kdy si svou konečnost uvědomíme, přináší to osvobozující pocit. A to přesto, že je s ním spojena i úzkost z jistého konce. Právě to, že navdzory tomuto vědomí ono riziko podstoupíme, je pak svým způsobem jistou formou „oběti“. Tyto „malé“ oběti přinášejí všichni, kteří do sféry jednání vstupují, avšak existuje ještě jeden druh oběti, kdy už možnost nebýt není jen teoretickým nebezpečím při střetu s druhým, ale kdy opravdu nastupuje její radikální či krajní forma, tedy obětování vlastního života. Radikální obět' je nekalkulovatelná, podle Patočky „není obětí za něco nebo za někoho, přestože je v jistém smyslu obětí za všechno a za všechny. V jistém smyslu je to obět' za nic, rozumíme-li tím to, co není žádné jsoucno“" (Patočka 2002b, 159).

Obět' je způsob, jakým se hlásíme k celku své existence, k níž patří i možnost nebýt. S touto svobodnou volbou musíme nakládat zodpovědně, je to nástroj, kterým v mezních situacích rozevíráme otřásající základ polis. Touto možností se teprve stáváme skutečně lidmi. Aby bylo možné hovořit o oběti, vždy se musí jednat o obětování něčeho, na čem nám záleží. To, na čem vždy záleží, je náš život. Není třeba ho však obětovat absolutně, to rozhodně není nic, k čemu by Patočka nabádal: „Člověk neobětuje něco, co je mu lhostejné, co se ho netýká; opravdová obět' je vždy obětí života bud' ve smyslu absolutním, nebo ve smyslu toho, co naše bytí stupňuje, činí bohatým, obsažným, naplněným“" (Patočka 2002b, 157).

Při nakládání s vlastní konečností v rámci života $\mathrm{v}$ polis tedy podstupujeme riziko, které se zdá být z pohledu těch, kteří do této sféry ještě nevstoupili, nesmyslné. A to především proto, že není kalkulovatelné. Obět' nelze $\mathrm{v}$ žádném ohledu převést na směnný obchod - něco za něco, nelze ji vyčíslit, spočítat, ani změřit. Tím pozbývá smyslu pro ty, kteří v těchto souvislostech vnímají svůj život v rámci mikro- i makrospolečenství, uspokojují svoje potřeby, hledají bezpečí a nechtějí být z tohoto bezpečí vytrhováni nutností svobodných rozhodnutí, která se nemají o co opřít (doslova jsou opřena o bezbřehé a děsivé „nic“). Chtějí mít pevnou půdu pod nohama, a to i ve druhém pohybu, kdy už instinktivní zaměření k naplnění 
slasti je překonáno asketismem a cílenou prací, jejíž výsledky jsou právě kalkulovatelné.

Radikální obět', která je podle Patočky pravou podobou jednání a politična, do této ekonomické sféry nespadá, vybočuje z ní. Z pohledu kalkulovatelnosti je zcela nepochopitelná. Přesto svůj smysl má, a to dokonce tak velký, že dokáže celou ekonomickou sférou jistot otřást naprosto zásadním způsobem. Ani lidé přebývající v neautentické existenci svých společenských rolí nemohou tento otřes zcela ignorovat. „A tak jsou oběti stálou př́tomností toho, co se nevyskytuje v kalkulacích technického světa“" (Patočka 2002b, 158). Nedomníváme se však, že by Patočka vyžadoval po členech polis, aby v zájmu celku obětovali svůj život. To by byla vskutku chybná interpretace Patočkova poselství. Podle našeho názoru hovoří Patočka o možnosti se svou konečností nakládat, kterou každý z nás má. Tato možnost vzbuzuje na jedné straně pocit ohrožení, zároveň ale dává člověku svobodu.

Radikální obět' jako aktivní uchopení vlastní konečnosti v době, kdy pospolitost upadá znovu do nevzrušivosti a mechanického přežívání, do recyklace a pouhé výroby a směny něco za něco, je dle Patočky právě to pozitivní. Tento všudypř́ítomný kalkul totiž radikální obět' prolamuje a obrací pozornost znovu na sílu činu, na jeho průběh. V radikální oběti se znovu pročistí síla lidského jednání. Obět' si zjednává pozornost, protože zasahuje každého a vytrhává nás z letargie. ${ }^{4}$

Zde se dostáváme k tomu, o co Patočkovi šlo především - k péči o duši. V souvislosti s vývojem evropských dějin (a zde se opět prolíná Patočkův metafyzický a historický přístup k vlastní filosofii) totiž varuje Patočka před rizikem, které by se jednoduše dalo vyjádřit jako návrat $\mathrm{k}$ druhému pohybu - ke kalkulovatelné sféře jsoucen, jimiž se zaobíráme, abychom unikli zneklidňující myšlence na vlastní konečnost. „Proti tématu péče o duši vystupuje do popředí jiné téma, které se zmocňuje oblasti za oblastí, politiky, ekonomie, víry a vědění, a přetváří je podle nového stylu. Nikoli starost o duši, starost být, nýbrž starost mít, starost o vnější svět a jeho ovládnutí, se stává dominantní" (Patočka 2002a, 88).

Právě návrat k onomu „být", tedy být autenticky, prokázat své lidství, je tou cestou, k níž bychom měli všichni směřovat. Pro Patočku to, zdá se, nebyla jen teoretická úvaha, jak později prokázal ve svém politickém angažmá. Ani u něj přitom nešlo primárně o radikální obět', ačkoli on sám nakonec o život přišel. „Patočka sám nám ukazuje, že existuje něco přesahujícího náš strach, naše zájmy, naše každodenní zvyky, naši námahu a práci, co dává smysl našim pocitům a aktivitám. ... že se můžeme zbavit

4 Srov. (Blecha 2018, 387). 
věcí světa, věcí, o kterých věříme, že je potřebujeme, ale že to můžeme udělat jen ve společnosti druhých. Patočka také odpovídá na otázku, proč bychom měli převzít rizika, která mohou tyto akty svobody doprovázet: abychom získali svobodu k otázce a přeměně našeho vztahu ke světu, k samotné totalitě, i když se zdá, že nemůžeme mít nejmenší vliv na náš každodenní život" (Melançon 2013, 600).

\section{Smrt a nesmrtelnost $\mathrm{v}$ polis}

Smrt je s polis spojena ještě v jiném ohledu. Druhého, se kterým se můžeme skutečně střetnout (ve smyslu aristotelského „jednání“, jehož cílem není žádný hmatatelný produkt) právě až v rámci polis a třetího pohybu naší existence, potřebujeme totiž opravdu nezbytně, a to kvůli nutnosti „svědectví“. Druhý zde vystupuje jako ten, jemuž se povaha jednání ukazuje a v jehož paměti (příbězích, hrdinských mýtech) přežívá. Jde o jakousi formu nesmrtelnosti, kterou umožňuje právě polis. V této sféře jednání, která se jako jediná odehrává př́mo mezi lidmi, se mohou vytvořit podmínky pro kontinuitu generací, pro pamět', a tím pro dějiny. Zdá se, že se zde vyskytuje rozpor - vědomí vlastního konce každého jednotlivce by přece mělo společnost paralyzovat natolik, že už by nemohla dále existovat. Vždyt' co je marnějšího než jednat s vyhlídkou na to, že všechno jednou skončí, natož pak s vědomím, že výsledkem tohoto jednání není konkrétní produkt, nýbrž pouze něco neurčitého, pouze čin? Jak to, že člověk vůbec vydrží existovat se smrtí před očima? Můžeme se v tomto případě ztotožnit s Arendtovou, že je to dáno tím, že jsme v rámci zmíněné plurality vždy zapleteni do napínavého příběhu, jehož rozuzlení neznáme a jehož význam se odkryje až poté, co dospěje ke svému konci. Ale i když nositel příběhu zemře, je nezbytné, aby tento jeho příběh někdo zprostředkoval ostatním. „... protože i hrdinský čin, který pro jednotlivce představuje nejvyšší nasazení, se v tkanivu lidských vztahů ukáže jen jako nově vetkané vlákno.... také Achilleus je ještě závislý na vypravěči příběhu svého činu... bez něho by jeho čin zůstal stejně pomíjivý jako jeho život" (Arendtová 2007, 251). Poskytovat př́ležitosti, díky nimž člověk mohl nabývat „nesmrtelné slávy“, měla právě polis. Těm, kteří se pustili do nějakého hrdinského činu, totiž zaručovala, že nežili a nejednali marně, že i bez básníků a vypravěčů po nich zůstanou „nepomíjivé památníky“ toho, co vykonali a co je hodno vzpomínky.

0 „nesmrtelnosti“ v tomto smyslu hovoří také Patočka: „... akumulace individuí, jejich organizovaná vzájemná souvislost, ustavičný styk a komunikace slovem, lidský způsob zjevování zjeveného, vytváří možnost prostoru pro existenci mimo sebe, pro pověst, slávu, trvání v paměti druhých. 
Organizovaný život vytváŕí podklad pro lidskou nesmrtelnost či aspoň pro to, co se jí nejvíce blíží (Patočka 2007a, 36). 0 tuto nesmrtelnost, zdá se, Patočkovi však primárně nejde. Jde především o uznání a ospravedlnění v očích druhých. A také o to, že tuto skutečnost jednající předpokládá, jinak by neměl odvahu se k jednání odhodlat. Protože to není samotný čin, ale jeho posouzení, které nakonec rozhodne o tom, „zda jeho aktér obstál, anebo ne, zda bude jeho jednání uznané, anebo zavržené..." (Blecha 2018, 271-272). S tím, jak poukazuje Blecha, souvisí především schopnost druhého odpouštět - právě jen díky ní jsme schopni se do takto nejistého podniku s nedohlédnutelnými důsledky pustit.

Vrat'me se nyní k předchozí Patočkově úvaze, která naznačuje to, co Arendtová později explicitně formulovala ve svém spise $O$ násilí. Poukazuje na zajímavý paradox. Tvrdí, že smrt je největší antipolitická zkušenost, protože člověk opouští společnost a svět jevů, které jsou základními předpoklady každé politiky. Znamená, že zmizíme ze světa jevů a opustíme společnost svých bližních. A přitom svět jevů i společnost bližních jsou základními předpoklady každé politiky. Smrt je tedy podle ní vyjádřením nejvyššího stupně osamělosti a bezmocnosti. Jakmile se s ní ale setkáváme kolektivně, mění radikálně svou podobu, protože si uvědomíme, že naše vlastní smrt je „provázena potenciální nesmrtelností skupiny, do které patříme, tedy nakonec nesmrtelností druhu" (Arendtová 2004, 50).

Arendtová poukazuje i na to, že lidská smrtelnost byla v předfilosofickém politickém myšlení chápána jako nejsilnější motiv pro politický čin (ačkoli v politické filosofii hraje toto téma podle ní pramalou roli) - právě jistota smrti vedla člověka odjakživa k tomu, aby se pokusil dosáhnout nesmrtelnosti svými činy. A k tomu měla sloužit polis: „Politika byla tudíž přesně tím prostředkem, $s$ jehož pomocí se dalo uniknout z rovnosti před smrtí do postavení zajištujíćího určitou míru nesmrtelnosti“ (Arendtová 2004, 50).

A právě z této úvahy Patočka vyvozuje význam lidské konečnosti pro polis. Svou konečností jsme si jistí, nezakrýváme ji, neuhýbáme před myšlenkou na vlastní smrt. Naše oběti (a ne nutně ty radikální) však nejsou marné. Mohou nám přinést nesmrtelnost, kterou nikde jinde než $\mathrm{v}$ polis získat nelze. Mýty a náboženství nás mohou uchlácholit, ale vlastní individuální nesmrtelnost můžeme získat jedině tím, že najdeme odvahu aktivně uchopit svou konečnost.

\section{Závěr}

Vstup do polis, umožněný otřesem jistot života pouze akceptovaného, vyžaduje vystát riziko s tím spojené a je neustálým bojem. Polis tak na jedné 
straně (podle Arendtové) zajištuje jisté zázemí, na druhé straně nám (dle Patočky) bere pevnou půdu pod nohama. Tento otřes je však nevyhnutelný, chceme-li (řečeno s Heideggerem) být autenticky. Pokud se pro toto rozhodneme, vstoupíme do sféry jednání, jsme vystaveni riziku, ztratíme jistoty poskytované společenstvím lidí, kteří nás ochraňovali, vydáváme se všanc.

Klíčové je v tomto ohledu právě odklonění se od věcí ve světě, které nám celek světa a existence zakrývají, a př́íklon k druhým lidem, s nimiž jsme nuceni jednat. Pojem jednání přejímá Patočka od Arendtové, ale zdůrazňuje, že prvním filosofem, který jednání člověka tematizuje, byl právě Aristotelés.

Patočka v souvislosti se třetím pohybem nepřestává sice mluvit o pohybu „pravdy“, ale postupně mnohem více zdůrazňuje jeho intersubjektivní a politický rozměr. Ten se zračí především v jednom z jeho názvů „sebezískávání sebevydáním“. V něm je obsažena klíčová myšlenka celého jeho konceptu: že totiž při vstupu do polis se musíme dát všanc druhému, ovšem nikdy přitom netušíme dopředu, jak tento střet s druhým dopadne. Můžeme přijít o všechno, můžeme ale mnohé získat. Především sebe. Tímto aktem se tedy přihlašujeme ke své konečnosti, integrujeme ji do své existence a přijímáme za to zodpovědnost se všemi možnými důsledky, které z toho vyplývají. Vydáním se všanc riskujeme, ale zároveň získáváme nástroj, kterým můžeme v rámci polis svobodně nakládat.

Předpolitická sféra je spojena s ignorováním konečnosti, nebo ochromeností ze strachu z ní. Člověkem se podle Patočky může stát teprve jedinec, který jedná $s$ vědomím, že může nebýt. Paradoxně tím však může získat nesmrtelnost.

\section{Literatúra}

ARENDTOVÁ, H. (2007): Vita activa neboli O činném životě. Praha: Oikoymenh.

ARENDTOVÁ, H. (2004): O násilí. Praha: Oikoymenh.

BARBARAS, R. (2016): Pohyb existence. Studie k fenomenologii Jana Patočky. Praha: Pavel Mervart.

BLECHA, I. (2018): Bytie a svet. Heidegger v kontexte. Košice: ACTA FACULTATIS PHILOSOPHICAE UNIVERSITATIS ŠAFARIKIANAE.

CAJTHAML, M. (2010): Evropa a péče o duši. Patočkovo pojetí duchovních základů Evropy. Praha: Oikoymenh.

FINK, E. (1969): Fink: Metaphysik und Tod. Stuttgart, Berlin, Köln, Mainz. HEIDEGGER, M. (1996): Bytí a čas. Praha: Oikoymenh.

KARFÍK, F. (2016): Jan Patočka a problém filosofie dějin. Ke kontextu Kacířských esejů. In: REFLEXE, 50.

MELANÇON, J. (2013): Jan Patočka's Sacrifice: Philosophy as Dissent. In: Continental Philosophy Review, 46(4), 577-602. 
PATOČKA, J. (2006): Česká filosofie v meziválečném období. In: Češi II, Praha: Oikoymenh.

PATOČKA, J. (2002a): Evropa a evropské dědictví do konce 19. století. In: Patočka, J.: Péče o duši III. Praha: Oikoymenh.

PATOČKA, J. (2002b): Nebezpečí technizace ve vědě u E. Husserla a bytostné jádro techniky jako nebezpečí u M. Heideggera, In: Péče o duši III. Praha: Oikoymenh.

PATOČKA, J. (2007a): Kacířské eseje o filosofii dějin. Praha: Oikoymenh.

PATOČKA, J. (2007b): Platón a Evropa. Praha: Filosofia.

PATOČKA, J. (1995): Tělo, společenství, jazyk, svět. Praha: Oikoymenh.

PATOČKA, J. (2007c): Věčnost a dějinnost. Praha: Oikoymenh.

Př́spěvek vznikl za podpory MŠMT, grant IGA_FF_2018_007.

\section{Mgr. et Bc. Lenka Jedličková}

Katedra filozofie, Filozofická fakulta

Univerzity Palackého v Olomouci

Kř́ízovského 12

77180 Olomouc

Česká Republika

lenka.jedlickova04@upol.cz 